\title{
Quiste óseo simple atípico. Presentación de un caso clínico
}

\author{
Atypical Simple Bone Cyst. A Case Report
}

L.R González¹, F. Stolbizer², G. Gianunzio², N. Mauriño3 , M.L. Paparella

Resumen: El quiste óseo simple (sinonimia quiste óseo traumático, quiste óseo solitario, quiste óseo hemorrágico) es un pseudoquiste intraóseo desprovisto de recubrimiento epitelial con un contenido seroso y/o hemático que en ocasiones puede estar ausente.

Es una patología poco frecuente que afecta a los huesos maxilares con predilección por el maxilar inferior.

El objetivo del presente trabajo es presentar un caso de quiste óseo simple en maxilar inferior que difiere de los habitualmente encontrados en los huesos maxilares en cuanto a su presentación clínica, radiográfica e histopatológica.

Palabras clave: Quiste óseo hemorrágico; Quiste óseo traumático; Quiste óseo solitario; Quiste óseo simple; Maxilar.

Recibido: 06.11.07

Aceptado: 25.11 .08

\begin{abstract}
The simple bone cyst (reported in the literature as traumatic bone cyst, solitary bone cyst, hemorrhagic bone cyst) is an intraosseous pseudocyst devoid of epithelial lining and filled with serous and/or hematic fluid that may also be lacking.

Is a an uncommon condition that usually affects the jaws, with predilection for the lower jaw.

The aim of the present work was to report a case of traumatic bone cyst of the jaw that differs from other maxillary bone cysts in its clinical, radiologic, and histologic presentation.
\end{abstract}

Key words: Hemorrhagic bone cyst; Traumatic bone cyst; Solitary bone cyst; Simple bone cyst; Jaw.

1 Cátedra de Cirugía y Traumatología Bucomáxilofacial III, Facultad de Odontología, Universidad de Buenos Aires. Residente del Servicio de Cirugía y Traumatología Bucomáxilofacial del Hospital Francés, Ciudad Autónoma de Buenos Aires. Argentina.

2 Jefes de Trabajos Prácticos, Cátedra de Cirugía y Traumatología Bucomáxilofacial III, Facultad de Odontología, Universidad de Buenos Aires. Servicio de Cirugía y Traumatología Bucomáxilofacial del Hospital Francés, Ciudad Autónoma de Buenos Aires. Argentina.

3 Profesor Adjunto, Cátedra de Cirugía y Traumatología Bucomáxilofacial III, Facultad de Odontología, Universidad de Buenos Aires. Jefe del Servicio de Cirugía y Traumatología Máxilofacial del Hospital Francés, Ciudad Autónoma de Buenos Aires. Argentina.

4 Especialista en Anatomía Patológica Bucal, Facultad de Odontología, Universidad de Buenos Aires. Argentina.

\section{Correspondencia:}

L.R. González

Universidad de Buenos Aires.

Facultad de Odontología.

C1122AAH- Marcelo T. Alvear 2142.

Buenos Aires, Argentina. 


\section{Introducción}

El quiste óseo simple es una lesión pseudoquística intraósea desprovista de recubrimiento epitelial con un contenido seroso y/o hemático que en ocasiones puede estar ausente, descrito inicialmente en los huesos maxilares por Lucas en el año 1929. ${ }^{1}$

Su etiopatogenia es incierta y controvertida lo que se evidencia en las múltiples y variadas teorías propuestas. ${ }^{2-4}$ La más aceptada fue planteada por Howe en el año 1965 y tiene su fundamento en los traumatismos. ${ }^{5} \mathrm{La}$ misma plantea que a partir de una hemorragia se formaría un hematoma intraóseo sin capacidad de organizarse y reparase produciendo una licuefacción que daría como resultado la formación de una neo cavidad.

El pico de incidencia está en la segunda década de vida ${ }^{5-8}$ y a diferencia de lo que ocurre en los huesos largos, donde hay una relación hombre - mujer 3:1, en los maxilares no tiene predilección por género. Su localización es casi exclusiva en el hueso mandibular, con mayor frecuencia en el cuerpo, seguido por la región sinfisiaria. Cuando se presenta en el maxilar superior la zona más afectada es el sector anterior. ${ }^{4,9}$

Generalmente la lesión es asintomática y suele ser descubierta en forma accidental durante estudios radiográficos de rutina. En ellos se presenta como una lesión osteolítica, radiolúcida, unilocular de límites definidos que en general no expande ni adelgaza las corticales óseas. Suele extenderse entre las raíces de las piezas dentarias con un contorno festoneado, sin desplazar ni causar rizólisis. Estas características son casi exclusivas del quiste óseo simple. La vitalidad de las piezas dentarias rara vez suele estar afectada. 4,10

El estudio macroscópico revela una cavidad unilocular que puede estar tabicada, con un contenido seroso y/o hemático, delimitada por una membrana fibrosa muy delgada, en ocasiones la cavidad puede estar totalmente vacía. Si su localización se encuentra por detrás del foramen mentoniano, se visualiza el nervio dentario inferior en el fondo de la misma ${ }^{11}$ por reabsorción del canal óseo. La exploración quirúrgica es necesaria para llegar a un diagnóstico definitivo, que por el curso de la manipulación producirá un sangrado dentro de la cavidad, y en la mayoría de los casos esto dará lugar a una regeneración del tejido óseo. ${ }^{11-13}$

Rara vez es necesario un segundo procedimiento quirúrgico. ${ }^{13-15}$

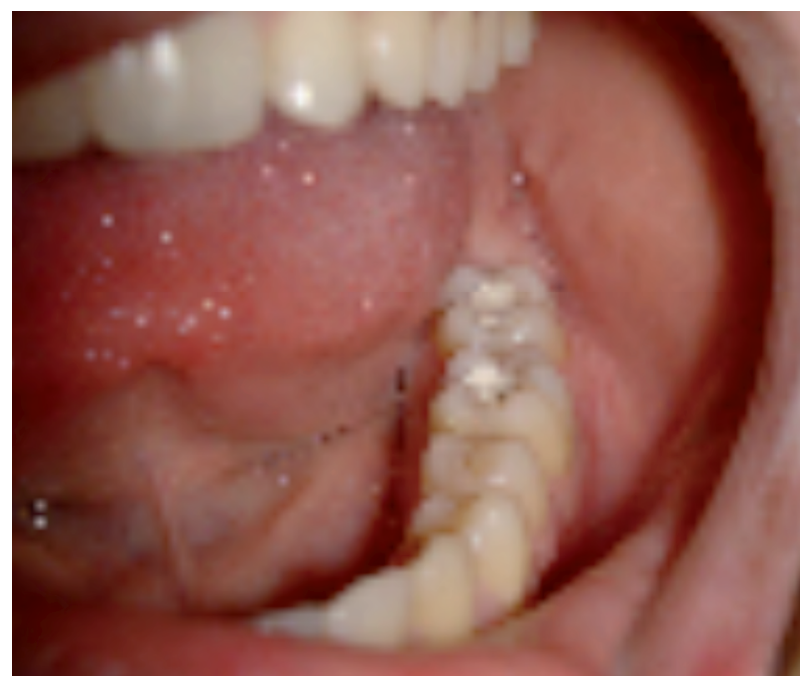
seas y la presencia de un tabique en la lesión.

Figure 1. CT: coronal slices. Note the expansion of the bone tables and the presence of a septum in the lesion.

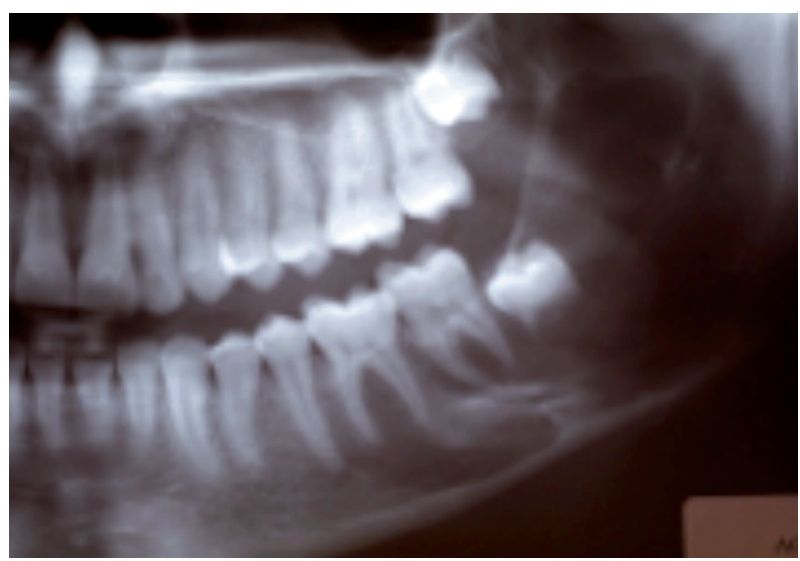

Figura 2. Rx panorámica. Lesión osteolítica que compromete tario de la pieza38 en relación con la lesión.

Figure 2. Panoramic radiography. Osteolytic lesion of the angle and ascending ramus. Note the dental germ of piece 3.8 in relation to the lesion.

\section{Introduction}

The simple bone cyst is an intraosseous pseudocystic lesion devoid of epithelial lining and containing serous and/or hematic fluid that sometimes may be absent. It was first described in the maxillary bones by Lucas in 1929. The etiopathogenesis of simple bone cyst is uncertain and controversial, as demonstrated by the many and varied theories proposed..$^{2-4}$ The most accepted hypothesis is that proposed by Howe in 1965, which is based on the idea of a traumatic injury. ${ }^{5}$ According to this hypothesis, the intraosseous hematoma arises from bleeding and lacks the capacity to organize and repair itself, resulting in liquefaction that eventually causes the formation of a neocavity. The peak incidence is in the second decade of life. 5-8 Unlike bone cysts in the long bones, where the male-female ratio is $3: 1$, in the jaw there is no predilection for either sex. It is located almost exclusively in the mandibular bone, most frequently in the body, followed by the symphyseal region. When simple bone cyst occurs in the upper maxilla, the anterior zone is most often affected. 4,9

The lesion generally is asymptomatic and usually is discovered accidentally during routine radiographic studies. On radiography, it presents as an osteolytic lesion that is radiolucid, unilocular, with well-defined limits, and usually does not expand or thin the cortical bone. It usually extends between the roots of the teeth, which produces a festooned contour, not displacing the teeth or causing rhizolysis. These characteristics pertain exclusively to simple bone cysts. Dental vitality is rarely affected. 4,10

The gross study reveals a unilocular cavity that may have septae, with serous and/or hematic content that is delimited by a very thin, fibrous membrane. The cavity sometimes can be empty. If it is located posterior to the mental foramen, the inferior dental nerve is visualized as floating in the foramen due to resorption of the bone canal. ${ }^{11}$ Surgical exploration is necessary to reach a definitive diagnosis that will produce 

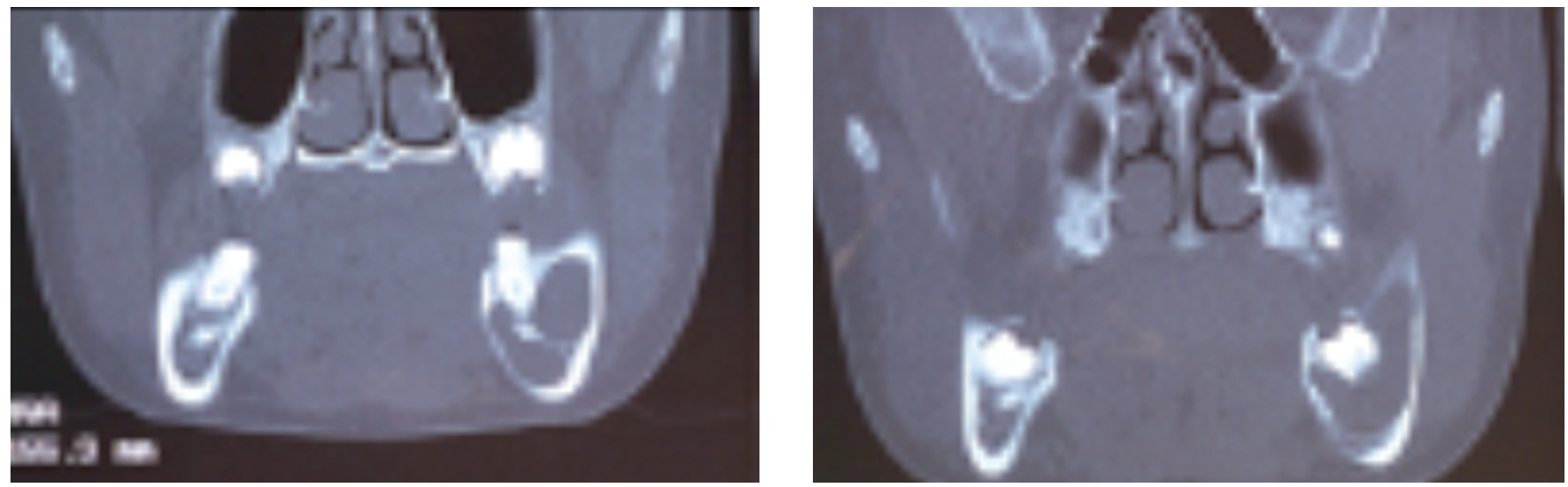

Figura 3. Imagen clínica preoperatopria. Nótese el aumento de volumen y borramiento del surco vestibular.

Figure 3. Preoperative clinical image. Note the increased volume and erased vestibular sulcus.

\section{Caso clínico}

Paciente de sexo femenino de 17 años de raza blanca que acudió al servicio de Cirugía y Traumatología Bucomáxilofacial del Hospital Francés de Buenos Aires con una asimetría facial de diez días de evolución. El examen clínico reveló un aumento de volumen a nivel del cuerpo del maxilar inferior del lado izquierdo que borraba el fondo de surco vestibular. La mucosa de revestimiento de la zona presentaba características de normalidad (Fig. 1). La paciente refería un intenso dolor a la palpación y el test de vitalidad pulpar fue negativo para las piezas dentarias 3,6 y 3,7. El estudio de imágenes reveló una lesión osteolítica, radiolúcida, unilocular y tabicada por distal del segundo pre-molar izquierdo que comprometía el cuerpo y la rama ascendente del maxilar inferior. Se observó también la presencia de un tercer molar retenido en relación a la cavidad y la pérdida de definición del conducto del nervio dentario inferior (Fig. 2).

Los cortes tomográficos permitieron evaluar la extensión real de la lesión.

La lesión medía $8 \times 3 \times 2 \mathrm{~cm}$ y expandía la tabla ósea vestibular (Fig. 3).

Bajo anestesia local se llevó a cabo una biopsia quirúrgica donde se obtuvo un fragmento de tejido blando cuya característica destacable fue su gran espesor.

Microscópicamente se observó un tejido fibrogranulomatoso con áreas mixoides, por presencia de cristales de colesterol y áreas hemorrágicas antiguas y recientes con reacción giganto celular con acúmulos de macrófagos con pigmento hemosiderínico (Fig. 4). Periféricamente se visualizó osteogénesis reaccional con formación de tra-

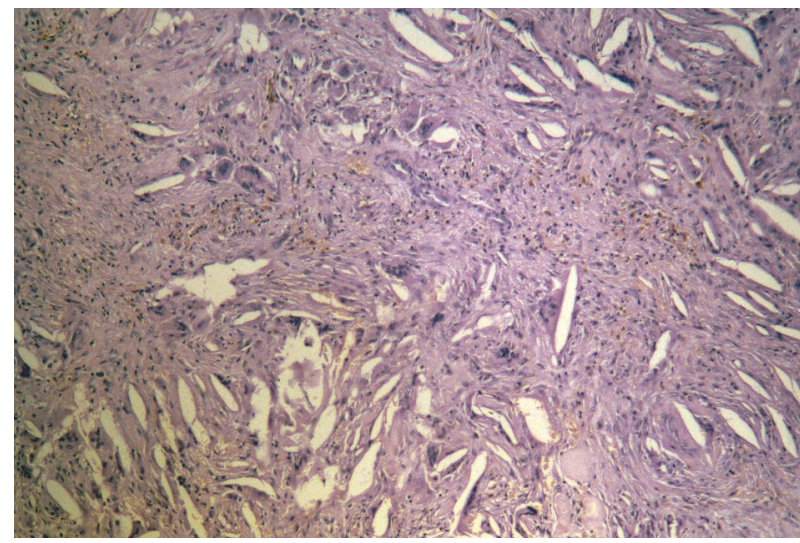

Figura 4. Mag. Orig. x 100. Tejido fibrogranulomatoso con reacción gigantocelular por cristales de colesterol.

Figure 4. Original magnification $\times 100$. Fibrogranulomatous tissue with a giant cell reaction due to cholesterol crystals.

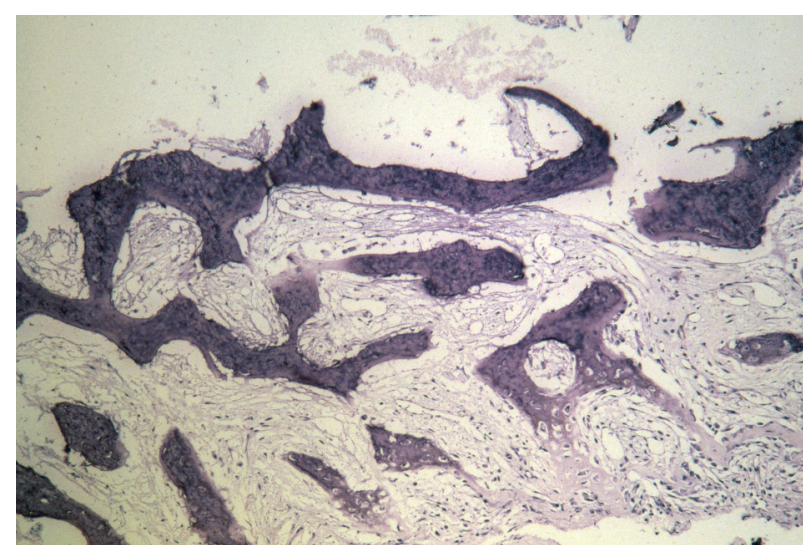

Figura 5. Mag. Orig. $x$ 100. Osteogénesis reaccional periférica. Figure 5. Original magnification $\times 100$. Peripheral reactive osteogenesis. bleeding into the cavity during maneuvers. In most cases, this will stimulate regeneration of the bone tissue. ${ }^{11-13}$

A second surgical procedure rarely is necessary. ${ }^{13-15}$

\section{Clinical case}

A 17-year-old woman of white race was seen in the Bucomaxillofacial Surgery and Traumatology Department of the French Hospital of Buenos Aires for facial asymmetry of ten days evolution.

The clinical examination revealed increased volume of the left mandibular body that erased the vestibular sulcus. The mucosa covering the zone appeared normal (Fig. 1). The patient referred intense tenderness and a test of pulp vitality was negative for dental pieces 3.6 and 3.7.

The imaging study revealed an osteolytic, radiolucid, unilocular, septated lesion under the second left premolar that affected the mandibular body and ramus. A retained third molar was observed in relation to the cavity and the definition of the inferior dental nerve canal was lost (Fig. 2).

Tomographic slices allowed evaluation of the true extension of the lesion. 
béculas osteoides (Fig. 5), y en algunos sectores se hallaron masas de material eosinófilo de aspecto fibrinoide con focos de calcificación (Fig. 6). El diagnóstico fue el de un quiste óseo simple con características similares a las observadas en el quiste óseo simple de los huesos largos. Previo tratamiento endodóncico de las piezas dentarias desvitalizadas y en un segundo procedimiento quirúrgico llevado a cabo bajo anestesia general, se abordó nuevamente la lesión realizando la exodoncia del tercer molar retenido y la enucleación total del tejido blando que revestía la cavidad quística (Fig. 7). Durante el procedimiento quirúrgico se produjo un profuso sangrado que fue controlado con maniobras locales de hemostasia. El lecho quirúrgico mostró indemne el paquete vásculonervioso que se encontraba libre por reabsorción del canal óseo (Fig. 8). El control a los tres, seis y doce meses mostró una evolución satisfactoria del proceso con reparación de los tejidos (Figs. 9-11).

\section{Discusión}

El quiste óseo simple (sinonimia quiste óseo traumático, quiste óseo solitario, quiste óseo hemorrágico) es una patología poco frecuente que afecta a los huesos maxilares. Desde su primera descripción en el año 1929, ha recibido múltiples denominaciones, muchas de las cuales tienen su origen en un intento de explicar su génesis. Si bien actualmente la teoría del trauma es la más aceptada como factor desencadenante, el antecedente de un trauma real es poco frecuente en los pacientes portadores de esta patología. La literatura internacional reporta una incidencia de trauma previo de entre el $17 \%$ y el $70 \% .^{3}$

Una de las características más frecuentes que acompaña al quiste óseo simple es la ausencia de manifestación clínica, por lo que el caso aquí reportado difiere en muchos aspectos a la presentación clínica-radiográfica clásica de estas lesiones. La asimetría facial como consecuencia de la alteración de la anatomía ósea normal, la presencia de tabiques óseos dentro de la cavidad quística, la presencia de una pieza dentaria retenida en relación con la patología, la sintomatología

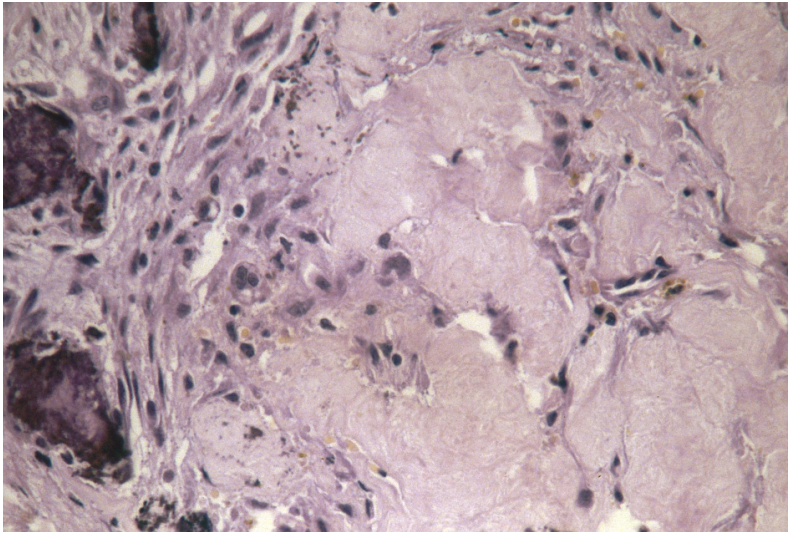

Figura 6. Mag. Orig. x 400. Material eosinófilo de aspecto fibrinoide con calcificaciones.

Figure 6. Original magnification $\times 400$. Eosinophilic material of fibrinoid appearance with calcifications.

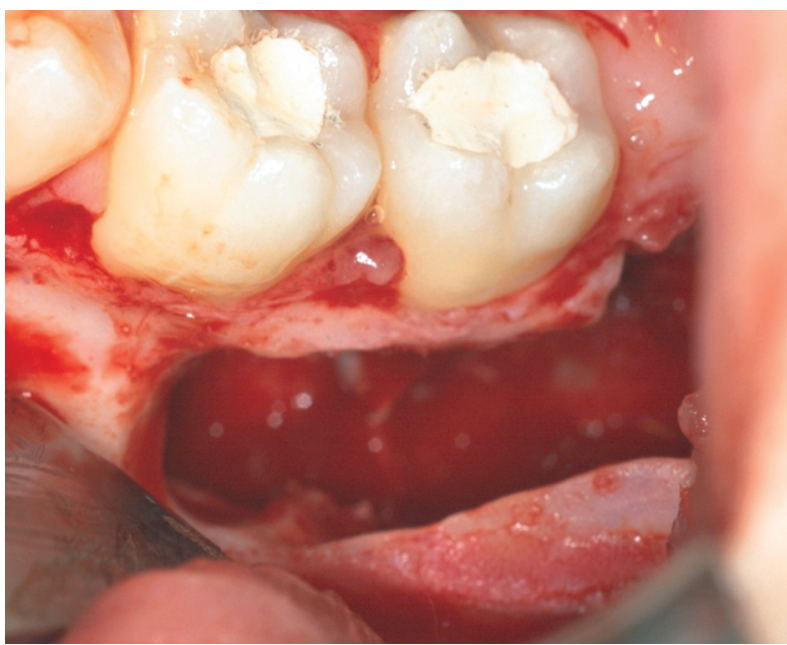

Figura 7. Abordaje quirúrgico. Nótese la presencia de un material serohemático en la cavidad.

Figure 7. Surgical approach. Note the presence of a serohematic material in the cavity.

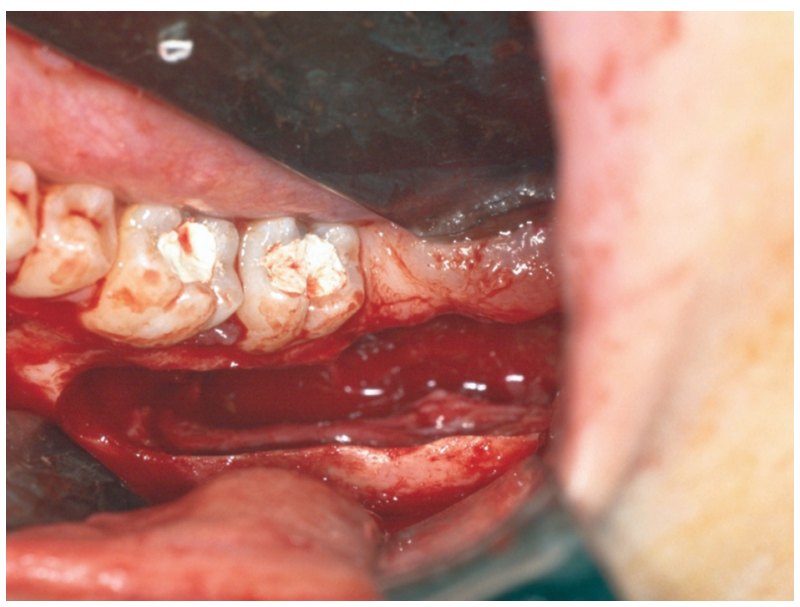

Figura 8. Fotografía intraoperatoria. Nótese el nervio dentario inferior libre dentro de la cavidad.

Figure 8. Intraoperative photograph. Note the inferior dental nerve floating freely in the cavity.
The lesion measured $8 \times 3$ $\times 2 \mathrm{~cm}$ and distended the vestibular bone table (Fig. 3). Surgical biopsy was performed under local anesthesia and yielded a soft tissue fragment that was notably thick.

Microscopically, fibrogranulomatous tissue was observed with myxoid areas, cholesterol crystals, old and recent hemorrhagic areas with a giant cell reaction and macrophage clumps, and hemosiderin pigment (Fig. 4). Peripherally, reactive osteogenesis with osteoid trabeculae formation (Fig. 5) was seen, with clumps of eosinophilic material of fibrinoid aspect and calcification foci (Fig. 6)

The diagnosis was simple bone cyst with characteristics similar to those of simple bone cyst of the long bone. After endodontic treatment of the devitalized teeth, the lesion was approached again in a second surgical procedure under general anesthesia to remove the retained third molar and enucleate the soft tissue that lined the cystic cavity (Fig. 7). During the surgical procedure, profuse bleeding was controlled with local maneuvers. The surgical bed showed an undamaged vasculonervous package that floated freely due to resorption of the bone canal (Fig. 8).

Follow-up at three, six, and twelve months confirmed the satisfactory evolution of the process with tissue repair (Figs. 9, 10 and 11).

\section{Discussion}

Simple bone cyst (synonyms: traumatic bone cyst, 
dolorosa y la falta de vitalidad de las piezas dentarias involucradas en la lesión son características poco frecuentes. Histológicamente también difiere de la presentación habitualmente encontrada en las lesiones de los huesos maxilares siendo las aquí reportadas más afines con las halladas en las lesiones que afectan a los huesos largos.

\section{Bibliografía}

1. Lucas C, Blum T. Do all cysts of the jaws originate from the dental system? I Am Dent Assoc 1929, 16:659-61.

2. World Heald Organization: Pathology and Genetics Head and Neck Tumors. Histological Classification of Odontogenic Tumours 2005.

3. Xanthinaki AA, Choupis KI,Tosis K, Pagkalos VA, Papanikolaou SI. Traumatic bone cyst of the mandible of possible iatrogenic origin: a case report and brief review of the literature. Head Face Med 2006;12;2:40.

4. Toller PA. Radioactive isotope and other investigations in a case of hemorrhagic cyst of the mandible. Br J Oral Surg 1964;2:86-93.

5. Howe GL. Haemorhagic cysts of the mandible. Br J Oral Surg 1965;3:55-76.

6. Cowan CG. Traumatic bone cysts of the jaws and their presentation. Int / Oral Surg 1980;9:287-91.

7. Hansen L, Sapone J, Sproat R. Traumatic bone cyst of jaw. Report of sixty-six cases. Oral Surg 1974;37:899-910.

8. Forsell K, Forsell H, Happonen RP, Neva M. Simple bone cyst. Review of the literature and analysis of 23 cases. Int J Oral Maxillofac Surg 1988;17:21-24.

9. Freedman $\mathrm{GL}$, Beigleman MB. The traumatic bone cyst: a new dimension. Oral Surg Oral Med Oral Pathol 1985;59:616-8.

10. Gupta M, Kaste SC, Hopkins KP. Radiologic appearance of primary jaw lesions in children. Pediatr Radiol 2002;32:153-68.

11. Precious DS, Mc Fadden LR. Treatment of traumatic bone cyst of mandible by injection of autogeneic blood. Oral Surg Oral Med Oral Pathol 1984;58:137-40.

12. Pradel W, Eckelt U, Lauer G. Bone regeneration after enucleation of mandibular cysts: comparing autogenous grafts from tissueengineered bone and iliac bone. Oral Surg Oral Med Oral Pathol Oral Rad and End 2006;101:285-90.

13. Misino J, Lavis JF,Tardif A, Peron JM. Kystes solitaires des maxillares: traitement chirurgical et suivi de six case. Rev Stomatol Chir MaxiIlofac 2004; 105:317-21.

14. Baqin ZH, Jayakrishnan A, Farthing PM, Hardee P. Recurrence of solitary bone cyst of the mandible: case report. Br J Oral Maxillofac Surg 2005;43:333-5.

15. Kuroï M. Simple bone cyst of the jaw: review of the literature and report of case. J Oral Surg 1980;38:456-9.

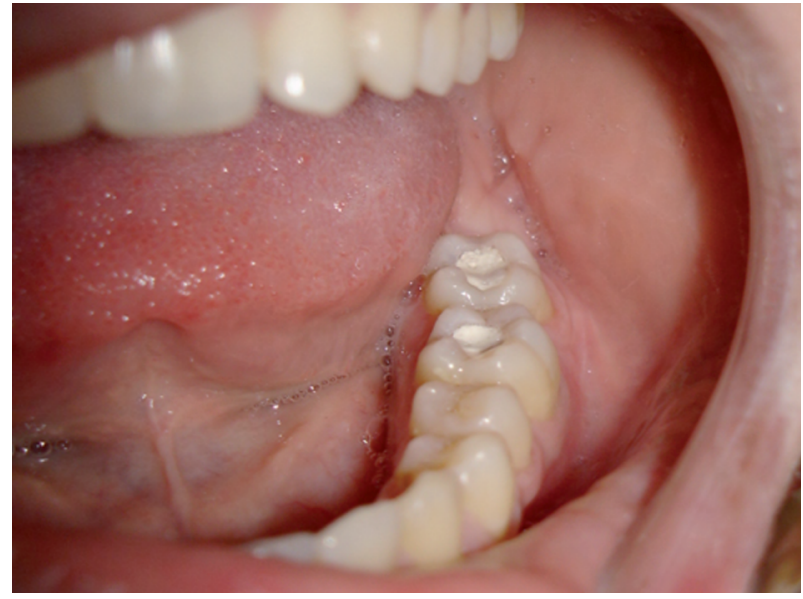

Figura 9. A los tres meses en la inspección clínica se observa un fondo de surco vestibular sin alteraciones.

Figure 9. At three months, an unaltered vestibular sulcus was observed during a clinical examination.

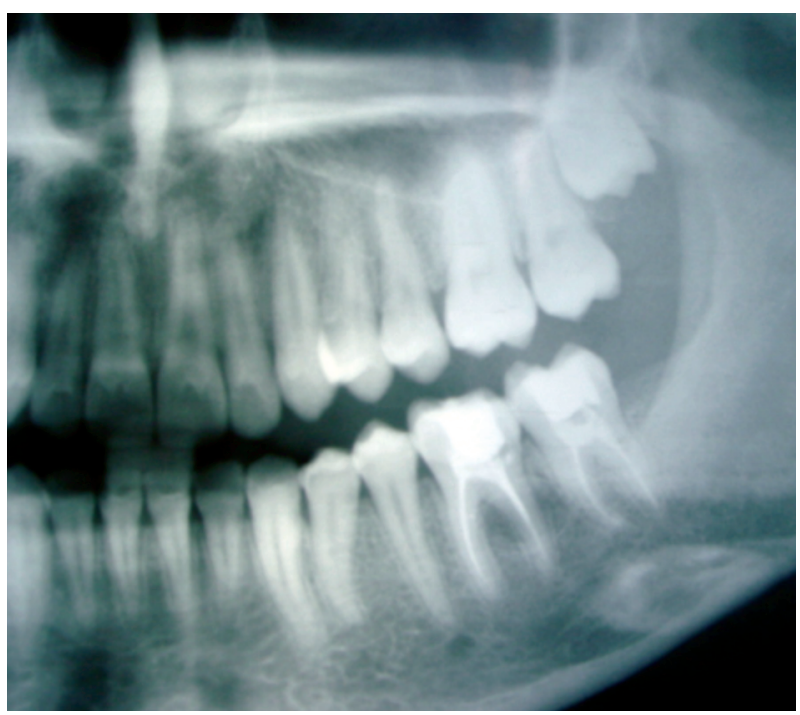

Figura 10. Rx panorámica a los seis meses.

Figure 10. Panoramic radiography at six months.

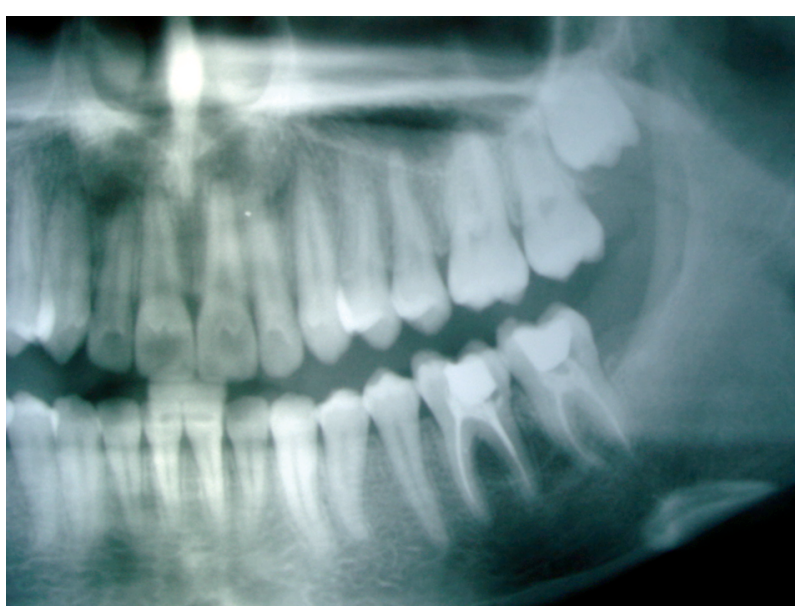

Figura 11. Rx panorámica a los doce meses.

Figure 11. Panoramic radiography at twelve months. solitary bone cyst, hemorrhagic bone cyst) is an infrequent pathology that affects the maxillary bones.

Since it was first described in 1929, the condition has received many denominations, many of which have their origin in attempts to explain its genesis. Although the current hypothesis of trauma as the trigger factor is the most accepted, a background of real trauma is infrequent in patients with this pathology. The international literature reports an incidence of previous trauma of 17 to $70 \%{ }^{3}$

One of the most common characteristics of the simple bone cyst is the absence of clinical manifestations, which is why the case reported here differs in many respects from the classic clinical and radiographic presentation of these lesions. Facial asymmetry as a result of alteration of the normal bone anatomy, the presence of bony partitions in the cystic cavity and a retained tooth in relation to the pathology, the painful symptoms, and the loss of vitality of the teeth involved in the lesion were uncommon characteristics. Histologically, it also differed from the usual presentation of lesions of the maxillary bones. The lesions reported here are more like the lesions of long bones. 